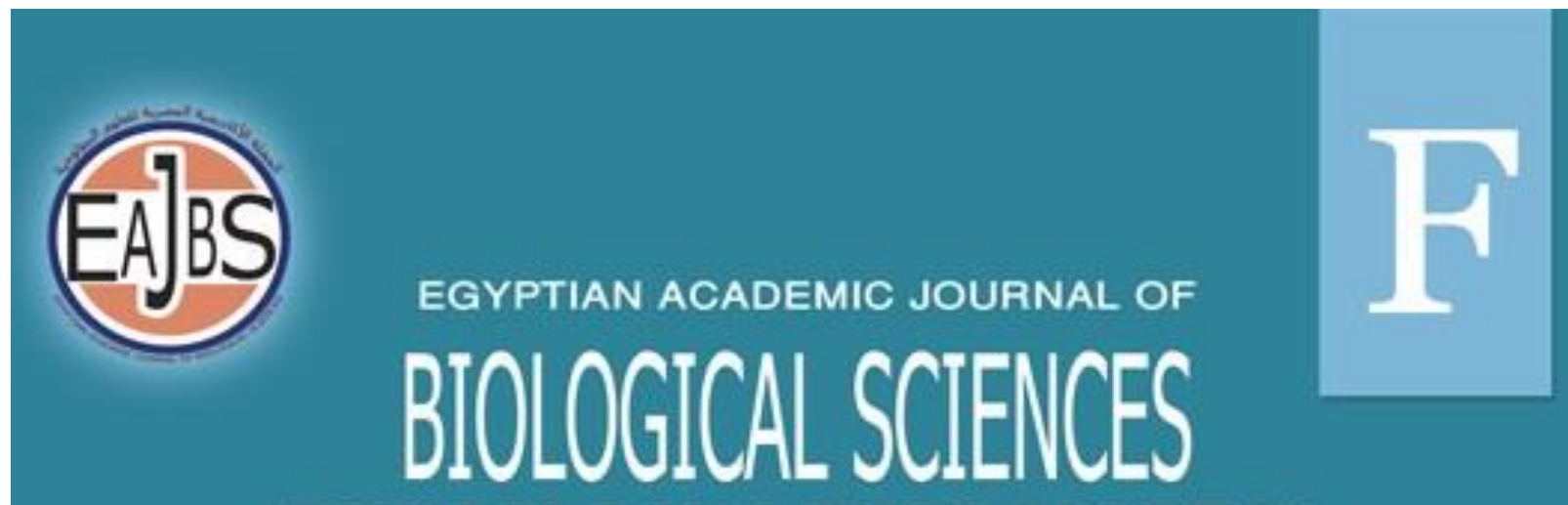

TOXICOLOGY \& PEST CONTROL

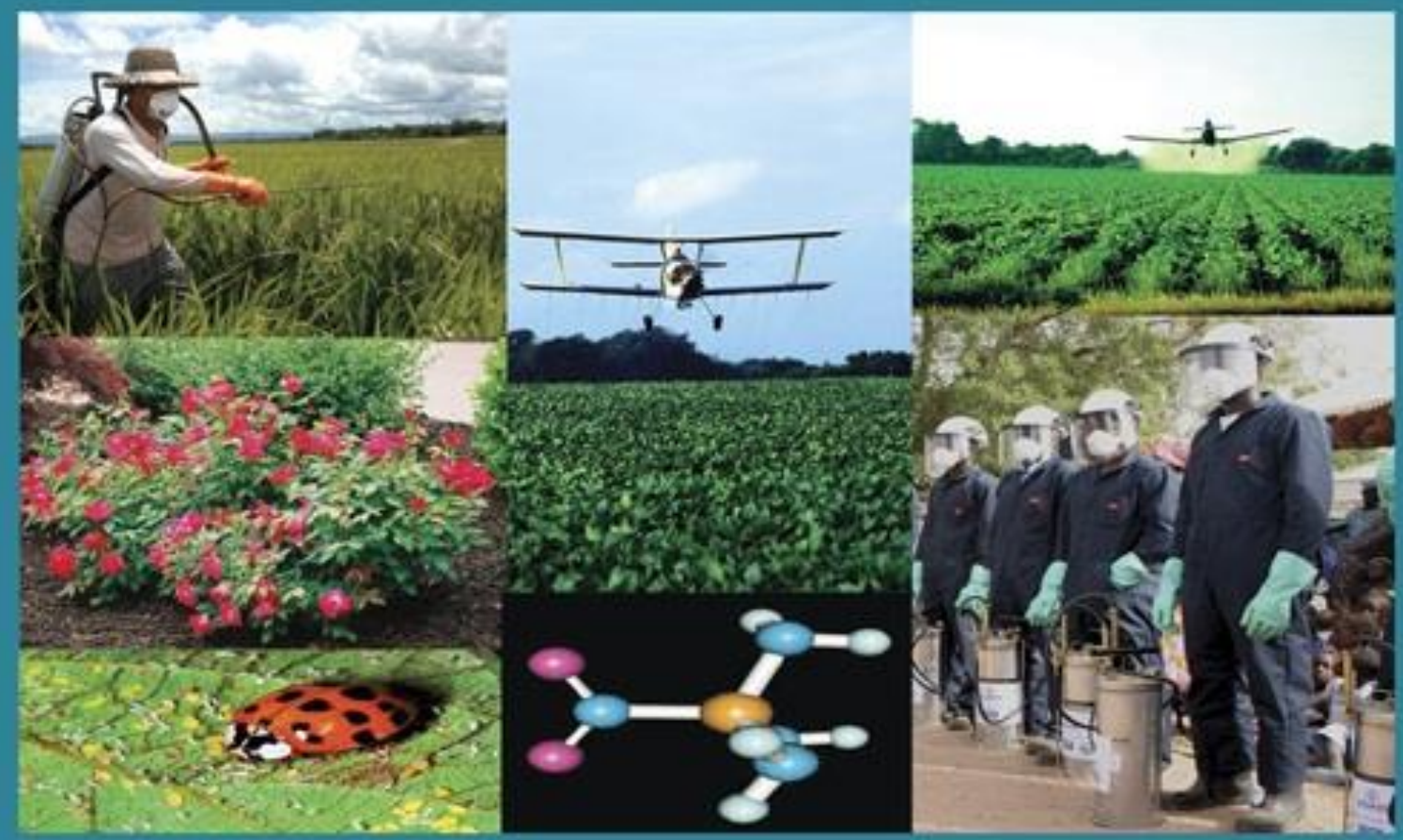

ISSN

2090-0791

WWW.EAJBS.EG.NET

Vol. 13 No. 1 (2021)

$\underline{\text { www.eajbs.eg.net }}$

Citation: Egypt. Acad. J. Biolog. Sci. (F.Toxicology\& Pest control) Vol.13(1)pp293-308(2021)

DOI: 10.21608/EAJBSF.2021.211778 
Egypt. Acad. J. Biolog. Sci., 13(1):293- 308(2021)

Egyptian Academic Journal of Biological Sciences

F. Toxicology \& Pest Control

ISSN: 2090 - 0791

http://eajbsf.journals.ekb.eg/

\title{
Biochemical and Histological Responses of Red Palm Weevil, Rhynchophorus ferrugineus Exposed to Sub-lethal Levels of Different Insecticide Classes
}

\author{
Farag A. Gh. Ahmed* and A. E. A. M. El-Sobki
}

Department of Plant Protection, Faculty of Agriculture, Zagazig University, Egypt E-mail*: Elfarag 4@zu.edu.eg

ARTICLE INFO

Article History

Received: $25 / 3 / 2021$

Accepted: 15/5/2021

\section{Keywords:}

Rhynchophorus

ferrugineus,

Chlorpyriphos,

Methomyl,

Spinosad,

Histopathology,

Biochemical

Aspects,

Oxidative Stress

\section{ABSTRACT}

By introducing the $9^{\text {th }}$ larval instar of the red palm weevil (RPW), Rhynchophorus ferrugineus, to feed on sugarcane stem dipped in insecticide solutions of chlorpyrifos, methomyl, and spinosad to monitor the biochemical and histological changes in larvae after $24 \mathrm{~h}$ exposure. The estimated $\mathrm{LC}_{50}$ values for chlorpyrifos, methomyl and spinosad were 109.73, 589.55 and $112.09 \mu \mathrm{g}$ a.i $/ \mathrm{ml}$, respectively. Exposure of RPW larvae to $\mathrm{LC}_{50 \mathrm{~s}}$ of the tested insecticides causes a significant inhibition in Acetylcholinesterase activity associated with increasing total protein in all treatments but alanine aminotransferase and aspartate aminotransferase activities enhanced with methomyl but decreased in spinosad-larvae treated. Chlorpyrifos was only significantly induced oxidative stress (increasing protein carbonyl indicator) followed by increasing antioxidant enzymes (catalase and glutathione peroxidase). While superoxide dismutase and glutathione peroxidase were reduced significantly in methomyl and spinosad treatments. Catalase activity raised significantly with chlorpyrifos followed spinosad. All the treatments of insecticides exhibited lower glutathione Stransferases activities especially in spinosad than chlorpyrifos treatments. The histological damage in the midgut of larvae treated included vacuolar degeneration, proliferation and necrosis of epithelial lining with destruction and separation of basement membrane and with desquamation in its lumen. In conclusion, spinosad insecticide was more effect on biochemical and histopathological responses of RPW than both methomyl and chlorpyrifos insecticides.

\section{INTRODUCTION}

Date palm Phoenix dactylifera L. is cultivated well especially in tropical and semitropical climates. It is considered an economic fruit crop in Egypt and the Middle East. Date palm fruits are a very good source of food with several medicinal qualities (Al-Dosary et al., 2016). Palms are infested by many harmful pests, but the red palm weevil is the most important of them at all (Salman et al., 2020). The red palm weevil (RPW), Rhynchophorus ferrugineus Olivier (Coleoptera: Curculionidae), is the main borer attacking palm trees (Milosavljević et al., 2019). Most of the popular date palm cultivars are also suitable for RPW infestation (Sallam et al., 2012).

The widespread RPW enabled it to expand its geographical range to extend to Asian, African, European and American countries, causing catastrophic damage to palm production 
(Giblin-Davis et al., 2013). RPW was an invasive pest reported in 1992 first recorded in date palm plantations of Sharqia and Ismailia Governorates in Egypt (Saleh, 1992) and converted to a major pest of date palm (Arafa, 2020). Because the high risk of RPW led to a lower economic threshold required implementation the effective control methods after date palms infestation reached 1\% (Faleiro et al., 2010). So monitoring the population density of $R$. ferrugineus is essential to protect palms (Vacas et al., 2013) which was conducted using pheromones and other semi chemicals in traps (Arafa, 2020) to determine the most appropriate time to apply the means of control.

Due to the difficulty of delivering biopesticides to the inside of the palm, lack of their efficiency and the appropriate conditions to ensure their sustainability in microhabitat besides their long incubation period compared with chemical insecticide (Mampallil et al., 2017). So, current control methods recommended for management against $R$. ferrugineus have focused on integrated pest management involving, chemical insecticide treatments (Salem et al., 2018).

When the RPW is detected, attention turns to chemical insecticides because of their quick action and effectiveness in pest control. Among the different chemical insecticides, organophosphate and carbamate insecticides were recommended for controlling $R$. ferrugineus (Faleiro, 2006; Murphy and Briscoe, 1999). Most of the insecticides used are neurotoxic in their main target i.e. Organophosphates and carbamates are anti-cholinesterase compounds (Gupta, 2011). But RPW developed resistance against used insecticides and phosphine fumigants which is considered a serious concern (Wakil et al., 2018). So lately, biologically based synthetic insecticides are applied as a curative insecticide against $R$. ferrugineus in date palm (Abdel-Salam et al., 2014; Mashal and Obeidat, 2019). The spinosad (spinosyns) is a natural and active insecticide derived from the rare soil-dwelling actinomycete bacterium called Saccharopolyspora spinosad (Mertz and Yao, 1990). Spinosad is a neurotoxin with a novel mechanism of action by activation of the nicotinic acetylcholine receptor and gamma-aminobutyric acid (GABA) receptor but at a unique site of action from imidacloprid and nicotine (Salgado, 1998).

After insecticides application under field conditions, the initial concentration deposited highly on the application site but decreased to lose activity and presence with sublethal concentration. The sub-lethal effect targets the activities of the enzymes in insects (Sabri et al., 2017) may be leading to mortality or disturbing the biological system (Yin et al., 2008). Depending on the stage of the insect, instar, enzyme type, and enzyme concentration, insecticidal chemicals had different effects on enzymatic activity. But the cells have evolved a complicated antioxidation system that comprises both exogenous antioxidants and endogenous antioxidant enzymes to resist the harmful effects of free radicals e.g., as catalase, glutathione S-transferase and superoxide dismutase (Samarghandian et al., 2014).

Therefore, the present study was constructed to determine a possible mechanism of the fat body injury after $R$. ferrugineus exposure to the sublethal short-term of insecticides (chlorpyrifos, methomyl and spinosad) to measure biochemical aspects in larvae homogenate. Likewise, oxidative stress indices and histopathological changes were determined, to contribute in understand the toxic sub-lethal effect of the tested insecticides and warn early of the possibility of developing resistance to insecticides applied to one of the study criteria. 


\section{MATERIALS AND METHODS}

\section{Founding the Colony:}

The pupae of the red palm weevil, $R$. ferrugineus collecting from the infested date palm field from El-Kasasin district, Ismailia Governorate, Egypt. To start the insect colony, the rearing of RPW was carried out in a controlled rearing incubator $\left(29 \pm 2{ }^{\circ} \mathrm{C}\right.$ and $60-70 \%$ $\mathrm{RH}$, with photoperiod (12:12 h L:D). the light intensity of about $30 \mathrm{FC}$ is provided with fluorescent tubes according to (Hamadah, 2019; Salama and Abdel-Razek, 2002). The RPW was maintained on the stems of sugarcane (Kaakeh et al., 2001).

\section{Insecticides Used:}

Three commercial insecticides included organophosphate "chlorpyrifos (Pyriban $\mathrm{A}^{\circledR}$ 48 \% EC)", carbamate "methomyl (Neomyl ${ }^{\circledR} 90 \%$ SP)" and biologically based synthetic "spinosad (Tracer ${ }^{\circledR} 24 \%$ SC)" were obtained from Central Agricultural of Pesticides Laboratory (CAPL), Agricultural Research Centre (ARC), Dokki, Giza, Egypt.

\section{Bioassay Experiment:}

The ninth larval instar of RPW was exposed to the tested insecticides using the dipping food technique (Salman et al., 2020; Shawir et al., 2014). The fresh sugarcane stalks were cut to pieces ( $\approx 15 \mathrm{~cm}$ in length, $1.5 \mathrm{~cm}$ diameter). These fresh-cut pieces were immersed in the prepared concentration solutions for 30 minutes. After the immersion period has passed, the treated pieces were air-dried then introduced to the starved larvae for nearly $6 \mathrm{~h}$ in glasses jars $(1 \mathrm{~L})$ with a perforated cover. In conjunction with these treatments, the untreated control consisted of the immersed pieces of sugarcane stalks in distilled water.

Based on preliminary experiments, different serial dilutions of each test insecticide were freshly prepared in distilled water to define the concentration range causing $20-85 \%$ mortality. Each treatment consisted of replicated three with 10 larvae/replicate. The larval mortalities were recorded after $24 \mathrm{~h}$ exposure.

After calculating the median lethal concentration $\left(\mathrm{LC}_{50}\right)$, the $9^{\text {th }}$ larval instar of the $\mathrm{RPW}$ was treated with the estimated $\mathrm{LC}_{50}$ values for the tested insecticides. The treatment was triplicated, each one contained ten larvae. The survival larvae were transferred into a 50 $\mathrm{ml}$ centrifuge tube then frozen directly at $-20{ }^{\circ} \mathrm{C}$ until the subject for biochemical assessments.

\section{Preparation of Larvae for Analysis:}

For determination enzymatic activities, larvae of the RPW were homogenized in icecold $50 \mathrm{mM}$ sodium phosphate buffer (pH 7.4) containing $0.1 \mathrm{mM}$ ethylenediaminetetraacetic acid (EDTA) yielding $5 \%(\mathrm{~W} / \mathrm{V})$ homogenate. The homogenates were centrifuged for 30 minutes at $4{ }^{\circ} \mathrm{C}$ at $12.000 \mathrm{~g}$. The supernatant was used to study enzyme activity and other biochemical parameters.

\section{Biochemical Assay:}

The supernatant of different treatments subjected determinations included:

1. Acetylcholinesterase (AChE) activity in R. ferrugineus, was obtained by adapting the technique described by (Ellman et al., 1961) by the addition of $10 \mu 1$ acetylthiocholine iodide $(3 \mathrm{mM} / \mathrm{l})$ and absorbance at $412 \mathrm{~nm}$ was read by spectrophotometer.

2. The activities of transaminases Aspartate aminotransferase (AST) and Alanine Aminotransferase (ALT) were determined according to (Reitman and Frankel, 1957).

3. Total protein (TP) level was quantified by the procedure of (Bradford, 1976).

4. Biomarkers of oxidative stress include:

a. Protein carbonyl (PC) content was assayed by the described method (Yan et al., 1995).

b. The activity of superoxide dismutase (SOD) was measured with the method of (Marklund and Marklund, 1974). 
c. The activity of glutathione-S-transferases (GST) was determined at $340 \mathrm{~nm}$ in the reaction medium containing phosphate buffer $(0.1 \mathrm{M}, \mathrm{pH} 6.5)$, reduced glutathione, GSH (1.0 mM), 1-chloro-2, 4-dinitrobenzoic acid (1.0mM) and a sample (Habig et $a l .$, 1974). Also, Glutathione peroxidase (GPx) activity was measured by (Beutler $e t$ al., 1963) method.

d. Catalase activity (CAT) was measured by the method of (Aebi, 1984). The reaction started by adding $\mathrm{H}_{2} \mathrm{O}_{2}(30 \mathrm{mM})$ to an appropriate volume of homogenate in $50 \mathrm{mM}$ sodium phosphate buffer with $\mathrm{pH}$ 7. Then, the absorbance was read at a wavelength of $240 \mathrm{~nm}$ within 3-min.

The percentage of changes of biochemical parameters was calculated according to (Sögüt $e t$ al., 2021) as $\Delta$ parameter $(\%)=($ control value - treatment value $) /($ control value $) \times 100$.

\section{Histopathological Changes:}

Treated and untreated larvae of the RPW were dissected in Ringer's solution. The midgut was isolated and fixed in Bouin's solution then embedded in paraffin. Many sections $5 \mu \mathrm{m}$ thickness were obtained and stained with hematoxylin and eosin (H \& E stain) according to the method of (Suvarna et al., 2018). The sections were examined by microscope under 400X.

\section{Statistical Analysis:}

Bioassay Experiments: Abbott's formula (Abbott, 1925) was used to compute the corrected mortality percentage based on control treatments. The dose-response relationship curve was statistically computed according to (Finney,1971) to calculate the median lethal concentration $\left(\mathrm{LC}_{50}\right)$ and regression line equation components of each insecticide using $\begin{array}{llllll}\text { Analystsoft } & \text { Biostat } & \text { Pro } & \text { 5 } & \text { S.4.3 } & \text { Software. }\end{array}$ Toxicity index $=\left(\right.$ lowest $\mathrm{LC}_{50}$ value $) /\left(\mathrm{LC}_{50}\right.$ value of insecticide $) \times 100$, was calculated according to (Sun, 1950).

Biochemical Assays: Data were expressed as the mean \pm SE of five replicates. The data were subjected to statistical analysis using one-way Analysis of Variance (ANOVA) and complemented with the least significant difference (LSD) by using SPSS program (Statistical Package for Social Science) version 25 for Windows (IBM SPSS Inc, USA). The statistical difference between the group means compared to the control group is indicated as follows: * $(\mathrm{p} \leq 0.05)$, and $* *(\mathrm{p} \leq 0.01)$.

\section{RESULTS AND DISCUSSION}

The RPW is one of the insects that were able to successfully invade new areas continuously causing to inflict heavy economic losses. Perhaps the reason for this success is the insect's strength and its great survival potential besides high adaptability and reproductive potential in the newly infested area. All these reasons make the RPW a serious insect pest that deserves careful study in terms of its response to the chemical pesticides applied to it, as well as the changes that occur internally after exposure to different pesticides, and the possibility of recovery from them (Haynes, 1988).

Therefore, the study concerns the diagnosing the current situation of the pest towards the widely used insecticides in controlling. Based on the obtained data in Table (1) and Figure (1) shows the results of bioassay experiments of the tested insecticides on the $9^{\text {th }}$ larval instar of RPW fed on sugarcane stalk dipped in the solutions of the tested insecticides. Chlorpyrifos showed the lowest $\mathrm{LC}_{50}$ recorded $109.73 \mu \mathrm{g} / \mathrm{ml}$ with the lowest range of fiducial limit (102.1569 and 117.7931) and toxicity index (Ti) attained 100\%. While spinosad occupied the second rank in potency with $\mathrm{LC}_{50}$ value $(112.09 \mu \mathrm{g} / \mathrm{ml})$ with fiducial limit (103.6774 and 121.1984) and $\mathrm{Ti}=97.89 \%$. Methomyl achieved the lowest potency $\left(\mathrm{LC}_{50}=589.55 \mu \mathrm{g} / \mathrm{ml}\right.$, and $\left.\mathrm{FL}=538.2336-643.8902\right)$ recorded $18.61 \%$ with Ti. As for the 
homogeneity of the tested strain of the RPW, it was found that it was more homogeneous with methomyl $(2.91 \pm 0.23)$, compared to the rest of the tested pesticides.

Table 1:Responses of the $9^{\text {th }}$ larval instar of the red palm weevil, Rhynchophorus ferrugineus, fed on sugarcane stalk dipped in the solutions of the tested insecticides.

\begin{tabular}{|c|c|c|c|c|c|c|}
\hline \multirow{2}{*}{ Insecticide } & \multirow{2}{*}{$\begin{array}{c}\mathbf{L C}_{\mathbf{5 0}} \\
(\mu \mathrm{g} / \mathrm{ml})\end{array}$} & \multicolumn{2}{|c|}{ LC $_{50}$ Fiducial Limit (95\%) } & \multirow{2}{*}{ Slope \pm SE } & \multirow{2}{*}{ Intercept } & \multirow{2}{*}{ Ti } \\
\hline & & Lower & Upper & & & \\
\hline Chlorpyrifos & 109.73 & 102.1569 & 117.7931 & $3.67 \pm 0.29$ & -2.48 & 100 \\
\hline Methomyl & 589.55 & 538.2336 & 643.8902 & $2.91 \pm 0.23$ & -3.07 & 18.61 \\
\hline Spinosad & 112.09 & 103.6774 & 121.1984 & $3.46 \pm 0.25$ & -2.09 & 97.89 \\
\hline
\end{tabular}

$\mathrm{LC}_{50}$ : Median lethal concentration; SE: standard error; Ti: Toxicity index

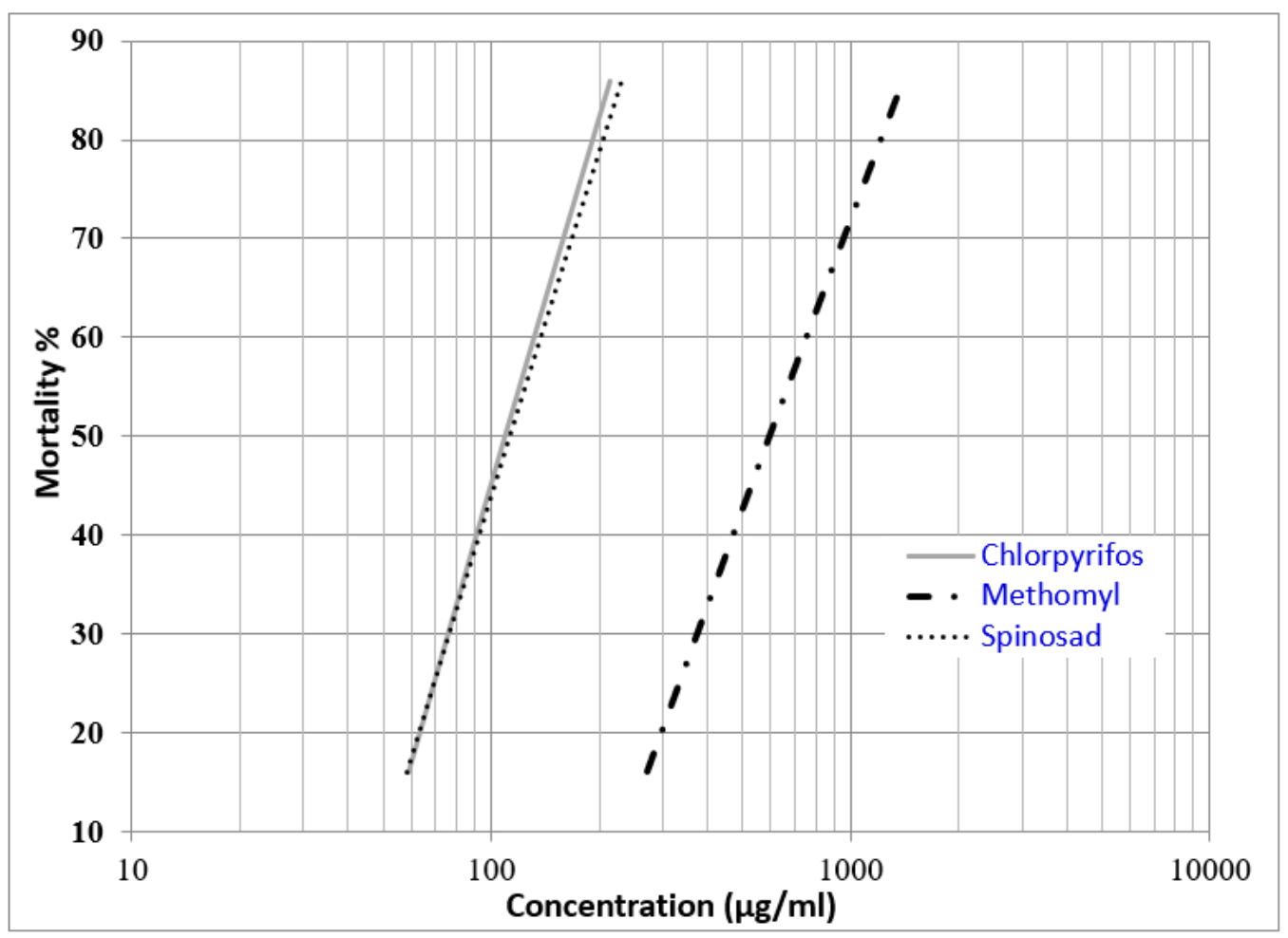

Fig. 1. Toxicity lines of chlorpyrifos, methomyl and spinosad on exposed the $9^{\text {th }}$ larval instar of the red palm weevil, Rhynchophorus ferrugineus, treated using the food dipping method

Chlorpyrifos estimated $\mathrm{LC}_{50}=2597 \mu \mathrm{g} / \mathrm{ml}$, against larvae (20 days old) using dipping food technique (Shawir et al., 2014). Chlorpyrifos was an effective insecticide against the

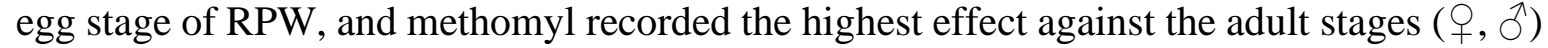
(Elgohary et al., 2015). The $\mathrm{LC}_{50}$ of females treated with spinosad was calculated at 44.3 $\mu \mathrm{g} / \mathrm{ml}$. The larval, pupa and adult instars of RPW are characterized by large and robust structures compared to other insect pests. The larval stage has a 13 larval instars (Dembilio and Jaques, 2012). Using dipping technique for sugarcane stalk in insecticide solution uptake a little amount on the outer surface. When taking the nutritional behavior of the insect inside the sugarcane stems, also the weight of the treated larvae " 9 th larval instar", requires a higher concentration reaching the median lethal concentration compared to other treatment methods such as the insect immersion method. Perhaps these variations explain the great discrepancy in the results of the bioassay of the RPW, not only at the level of the same phase but also according to the different gender tested as reported (Elgohary et al., 2015). 
Acetylcholinesterase (AChE) is an enzyme that catalyzes the breakdown of the neurotransmitter acetylcholine at peripheral and central synapses in the nervous system of insects (Bourne et al., 2016). AChE is also an important target site for insecticide action (organophosphorus and carbamates) in the central nervous system of insects (Naqvi et al., 1994; Nathan et al., 2008). During this investigation, AChE activities of RPW larvae decreased throughout the experiment following treatment with methomyl and spinosad. The decrease in AChE activities can be related to the mode of action of most pesticides.

Chlorpyrifos and methomyl are cholinesterase inhibitors, acetylcholinesterase (AChE) is a primary target site for carbamate and phosphorous insecticides. While spinosad is mainly binding the nicotinic acetylcholine receptor to work as an agonist but at a site distinct from that of nicotine or the neonicotinoids (Tomlin, 2009). The obtained data in Table (2) showed that methomyl and spinosad treatment provide significant inhibition of AChE activity in RPW larvae at $\mathrm{p} \leq 0.01$ but non-significant inhibition was observed with chlorpyrifos. The \% changes of AChE activities were 31.18 and $41.75 \%$ in larvae treated with methomyl and spinosad respectively. The surpassed Spinosad potency as AChE inhibitor was reported on different insects. Spinosad decreased AChE activity in different organs of honeybee workers at varying concentrations, according(Rabea et al., 2010). Also, Spinosad had anticholinesterase action against one Electrophorus electricus acetylcholinesterase and two Drosophila melanogaster acetylcholinesterases (Bucur et al., 2014).

Although the insecticide spinosad is not specific to inhibit the AChE it considers a secondary target compared with chlorpyrifos and methomyl which targets mainly AChE. Therefore Spinosad has a potent insecticidal effect on RPW because of aiming two vital targets in insects (Müller, 2018). While surpassing the AChE inhibition of chlorpyrifos compared with methomyl due to the aging of organophosphorus insecticides with AChE causing irreversible binding. In contrast with the carbamate insecticide methomyl, the binding with Ache is reversible (Vale and Lotti, 2015). Besides, the high hydrophilicity of methomyl other insecticides reduced the uptake amount and reduced the permeability of parent compounds through the hydrophobic barriers e.g., insect and plant cuticle and internal barriers surrounding neurons reaching the target site (Durlin et al., 1987).

Transaminases (ALT and AST) help in the production of energy (Azmi et al., 1998), and serve as a strategic link between carbohydrates and protein metabolism and are known to be altered during various physiological and pathological conditions. The activity of both ALT and AST increased in larvae treated with methomyl this may be attributed to the occurrence of reversible binding between insecticide and enzymatic site of action on the enzyme surface. This may be because the relationships between protein synthesis and transaminase levels were affected by the hormonal control of protein synthesis and neurosecretory hormones which are involved in the regulation of transaminase levels (Etebari et al., 2005).

ALT and AST activities were affected highly significantly after exposure to insecticides, decrease spinosad treatment (65.01 and 51.29\%) and an increase in methomyl treatment ( 81.40 and $105.55 \%$ ) compared to check treatment which did not show a significant difference from the chlorpyrifos treatment, as illustrated in Figure (2). Conversely, the higher activities of ALT and AST in spinosad may relieve the biochemical impact on total protein content causing a significant increase (4.81) compared to methomyl treatment that showed a highly significant positive effect on ALT and AST activities reflected highly significantly adversely on total protein amount. On the contrary, chlorpyrifos was not a significant difference in the control treatment. 
Table 2 :Changes in Acetylcholinesterase activity of the red palm weevil, Rhynchophorus ferrugineus, hemolymph exposed to median lethal concentrations of different insecticide classes.

\begin{tabular}{|c|c|c|c|c|}
\hline \multirow{2}{*}{ Parameters } & \multicolumn{4}{|c|}{ Treatments } \\
\cline { 2 - 5 } & Control & Chlorpyrifos & Methomyl & Spinosad \\
\hline $\begin{array}{c}\text { Acetylcholinesterase } \\
(\boldsymbol{\mu M} / \mathbf{m i n})\end{array}$ & $500.87 \pm 13.724$ & $\begin{array}{c}469.86 \pm 30.293 \\
(6.19)\end{array}$ & $\begin{array}{c}344.68 \pm 8.615^{* *} \\
(31.18)\end{array}$ & $\begin{array}{c}291.75 \pm 12.617^{* *} \\
(41.75)\end{array}$ \\
\hline
\end{tabular}

Values are expressed as Mean $\pm \mathrm{SE}(\mathrm{n}=5)$; Numbers between parentheses refer to "change percentage (\%)"ascribed to control; *and ** significant versus control at $\mathrm{P} \leq 0.05$, and 0.01 respectively.
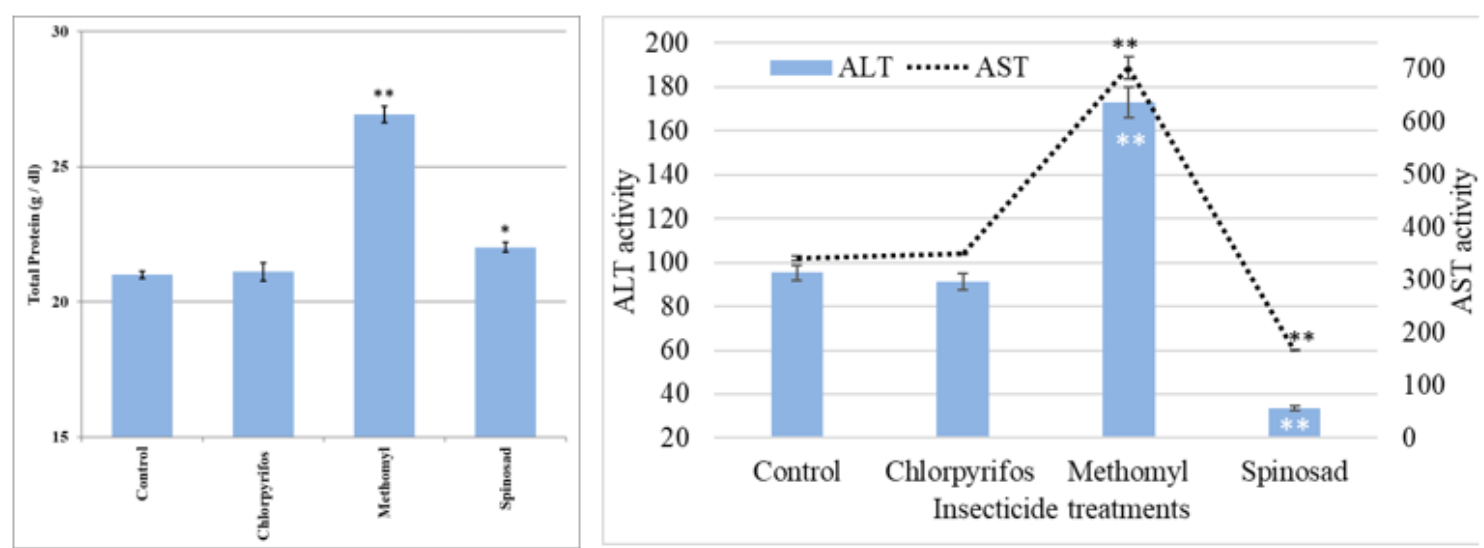

Fig. 2: Changes in protein content and enzymes (ALT and AST) in the red palm weevil, Rhynchophorus ferrugineus hemolymph exposed to median lethal concentrations of different insecticide classes. ${ }^{*}$, and $* *$ significant versus control at $\mathrm{P} \leq 0.05$, and 0.01 respectively

The lower activities of ALT and AST after exposure to spinosad in our result were documented by (Abdel-Razik and Mahmoud, 2017) with Jojoba, Simmondsia chinensis extract on cotton leafworm, Spodoptera littoralis (Boisd.). Also, (Gaaboub et al., 2012) reported that Neemix, caused a significant decrease in the activity of GPT of the treated 4th instar larvae of $S$. littoralis. The methomyl trend in insects was also the same in the Spodoptera littoralis larvae with emamectin benzoate, abamectin and spinosad (Megahed et al., 2013). Chlorpyrifos decreased (ALT) levels insignificantly of Spodoptera littoralis (Magdy et al., 2019). On the other hand, spinosad treatments induced a significant inhibitory effect on transaminases (ALT and AST) activities. These results agree with (Assar et al., 2016) by emamectin and spinetoram, and hexaflumuron against the 4th instar larvae of Spodoptera littoralis and with (Abd-El-Aziz, 2014; Amin and Fahmy, 2011) using spinetoram reduced both GOT and GPT of Spodoptera littoralis. Also, Spinosad and lufenuron significantly increased the ALT of Spodoptera littoralis (Magdy et al., 2019).

Oxidative stress, an imbalance toward the pro-oxidant side of the prooxidant/antioxidant homeostasis. Because of the relatively early synthesis and relative stability of carbonylated proteins, using them as biomarkers of oxidative stress is favored. (Dalle-Donne et al., 2003). Influence of antioxidant and oxidative stress parameters in the RPW, exposed to sub-lethal concentrations of the tested pesticides were included in Table (3). The results revealed that protein carbonyl (PC) level was highly raised significantly in chlorpyrifos-treated larvae recorded a $12.48 \%$ increase $(\mathrm{p} \leq 0.01)$. Long-term exposure to chlorpyrifos increased the production of reactive oxygen species (ROS), resulting in cell oxidative damage and a reduction in antioxidant capacity. while protein carbonyl reduced significantly in spinosad treatment (43.27\%) compared with unexposed larvae and methomyl treatment. 
Table 3 :Changes in protein carbonyl content and activities of antioxidant enzymes in the red palm weevil, Rhynchophorus ferrugineus exposed to sub-lethal concentrations of different insecticide classes.

\begin{tabular}{|c|c|c|c|c|}
\hline \multirow{2}{*}{ Parameters } & \multicolumn{4}{|c|}{ Treatments } \\
\cline { 2 - 5 } & Control & Chlorpyrifos & Methomyl & Spinosad \\
\hline $\begin{array}{c}\text { Protein carbonyl } \\
(\mathrm{nM} / \mathrm{ml})\end{array}$ & $72.69 \pm 0.976$ & $\begin{array}{c}81.76 \pm 1.101^{* *} \\
(-12.48)\end{array}$ & $\begin{array}{c}69.63 \pm 2.52 \\
(4.21)\end{array}$ & $\begin{array}{c}41.24 \pm 1.512^{* *} \\
(43.27)\end{array}$ \\
\hline $\begin{array}{c}\text { Superoxide dismutase } \\
(\mathrm{U} / \mathrm{ml})\end{array}$ & $6.63 \pm 0.041$ & $\begin{array}{c}6.83 \pm 0.095 \\
(-3.02)\end{array}$ & $\begin{array}{c}4.77 \pm 0.006^{* *} \\
(28.05)\end{array}$ & $\begin{array}{c}6.07 \pm 0.084^{* *} \\
(8.45)\end{array}$ \\
\hline $\begin{array}{c}\text { Catalase }(\mathrm{U} / \mathrm{mg}) \\
\text { Glutathione peroxidase } \\
(\mathrm{nM} / \mathrm{ml})\end{array}$ & $2.07 \pm 0.063$ & $\begin{array}{c}5.33 \pm 0.210^{* *} \\
(-157.49)\end{array}$ & $\begin{array}{c}1.91 \pm 0.096 \\
(7.73)\end{array}$ & $\begin{array}{c}10.73 \pm 0.255^{* *} \\
(-418.36)\end{array}$ \\
\hline $\begin{array}{c}\text { glutathione-S-transferases } \\
(\mu \mathrm{mol} / \mathrm{min})\end{array}$ & $19.25 \pm 0.995$ & $\begin{array}{c}16.50 \pm 0.473^{*} \\
(14.29)\end{array}$ & $\begin{array}{c}17.57 \pm 0.845 \\
(8.73)\end{array}$ & $\begin{array}{c}13.57 \pm 0.649^{* *} \\
(29.51)\end{array}$ \\
\hline
\end{tabular}

Values are expressed as Mean \pm SE $(n=5)$; Numbers between parentheses refer to "change percentage (\%)"ascribed to control; *and ** significant versus control at $\mathrm{P} \leq 0.05$, and 0.01 respectively.

Antioxidant enzymes (SOD, CAT, and GPx) are also called enzymes of the protective cellular system as superoxide dismutase can enhance $\mathrm{H}_{2} \mathrm{O}_{2}$ production from $\mathrm{O}_{2}$ through dismutation while catalase and peroxidase are known to catalyze $\mathrm{H}_{2} \mathrm{O}$ production from $\mathrm{H}_{2} \mathrm{O}_{2}$. These reactions can result in the elimination of bio-membrane damage by reactive oxygen species, ROS, (Shuang-yang et al., 2001). During this trial, the activities of antioxidant enzymes (SOD and GPx) dropped whereas the activity of CAT increased. Reduced antioxidant enzyme activity (SOD and GPx) can lead to a reduction in ROS clearance, which can denature several biomolecules in the insect body. The denaturation of biomolecules can stop all the cellular processes, so leading to the death of the insect (Felton, 1995).Superoxide dismutase (SOD) activity was decreased significantly at both methomyl and spinosad treatments may be due to the absence of oxidative stress in both treatments as shown in Table (3).

Catalase function is mainly destructing of hydrogen peroxide to water and oxygen. Hydrogen peroxide can oxidize a variety of substrates also inflicting biological harm. The Fenton reaction is a complicated reaction that can produce both hydroxyl radicals and higher oxidation states of iron. Catalase activities were raised significantly vigorously in spinosad $(418.36 \%)$ and Chlorpyrifos (157.49\%) treatments comparing control.

In insects, detoxification of insecticides is mainly accomplished by glutathione-Stransferase, GSTs, (Claudianos et al., 2006). Our findings showed reduce in GSTs activities following chlorpyrifos and spinosad treatments which are in line with the findings of (Ali et al., 2017) by the insecticide matrine against Bemisia tabaci and (Jia et al., 2016) who found a comparable decrease in enzyme activity in Locusta migratoria after using chlorantraniliprole and Metarhizium anisopliae together. Although there are few reports on changes in GST activity as a result of the studied pesticides, the magnitude of changes can vary according to the insect species targeted, the type of insecticide employed, and the dosage of insecticide utilized. Also, the reduction in GST activities in response to different classes of insecticide throughout the experimental period can be related to the sequence of chemical's/pathogen's action against $R$. ferrugineus (Ali et al., 2017).

The cytosolic enzyme glutathione peroxidase (GPx) catalyzes the conversion of hydrogen peroxide to water and oxygen (Fanucchi, 2004). A reduction was recoded on GPx activity in all experimental exposure to the tested insecticides. In addition, exposure of RPW larvae to the sublethal level of chlorpyrifos and spinosad caused significant inhibition of glutathione-s-transferase and elevation of catalase activity compared to the untreated group. 
In insects, detoxification of insecticides is mainly accomplished by glutathione-Stransferase, GSTs, (Claudianos et al., 2006; Simon, 1996), also, GSTs may contribute to the antioxidant defense in insecticide resistance (Che-Mendoza et al., 2009; Vontas et al., 2001). GST was reduced significantly in spinosad (29.50\%) followed by chlorpyrifos (14.29) from the control treatment.

The activity of the enzymes varies according to the organ, route of administration, the dosage, gender in which it is estimated. As observed on $R$. ferrugineus treated with $\mathrm{LC}_{50}$ of spinosad to study antioxidative responses showed inhibition of the activities of SOD, and GST in the midgut. However, in the testes, no significant changes in the activity of these enzymes were identified. (Abdelsalam et al., 2016). On the other hand, in adult females a significant increase in CAT activity only in response to higher concentrations (Abdelsalam et al., 2020).

A longitudinal muscle layer occurs outwardly followed by an interior circular muscle layer midgut in $R$. ferrugineus (Olivier) larvae, as shown in a cross-section (CS) of the typical midgut (Figs. 3a \& b). While CS of the midgut treated with chlorpyrifos revealed that vacuolar degeneration, thinning, and desquamation of the epithelial lining also, necrosis with separation of the basement membrane (Figs. 4a, b \& c). Where destruction, degeneration, and necrosis with separation of the basement membrane of the epithelial lining and with desquamation in its lumen were found in the midgut of larvae treated with methomyl (Figs. 5a, b \& c). On the other hand, the histopathological damages were severity in spinosad-larvae treated as shown in (Figs. 6a-c). The pathological changes were severed vacuolar degeneration, necrosis, and proliferation of epithelial lining with separation and destruction of the basement membrane.

Alterations in the cellular organelles of the midgut, Malpighian tubules, and testes of $R$. ferrugineus were evaluated for spinosad histopathological changes. (Abdelsalam et al., 2016). Also, varying intensity changes in cell organelles (Abdelsalam et al., 2020). In Culex pipiens, exposure resulted in epithelial cell degeneration, the disintegration of plasma and basement membranes, and severe damage of the cellular microvillar system in the midgut. (El et al., 2020). Exposure of Partamona helleri to spinosad caused morphological alterations in the midgut and intensified the processes of apoptosis, autophagy and oxidative stress in this organ (Araujo et al., 2019). While The spinosad $\mathrm{LC}_{50}$ caused disorganization of the epithelia of tested organs and induced oxidative stress and cell death on A. mellifera. (Lopes et al., 2018).

The midgut of the red palm larvae contains epithelial cells, and the distinctive features of the midgut were the villi. The interior surface of the epithelial cells is provided with borders. The basement membrane supports epithelial cells. (Abd El-Fattah et al., 2020). The obtained results for pathological damage of treated RPW larvae, R. ferrugineus, revealed that midgut was sensitive to the tested insecticides. A similar result was obtained by (Abd El-Fattah et al., 2020) who reported that the damage included vacuolation of cytoplasm, analyzes and destroyed nuclei of the epithelial cells of RPW larvae treated with imidacloprid and chlorpyrifos and their nano form as well as by (Abdel-Ghaffar, 2004) from different insecticides against different insects. Also, (Ahmed, 1995) reported that the histopathological action of some pesticides was observed to cause epithelial cell expansion and the formation of vacuoles. On the other hand, (Hussein et al., 1994) mentioned that the effect on midgut may be due to digestion and absorption of insecticides. 

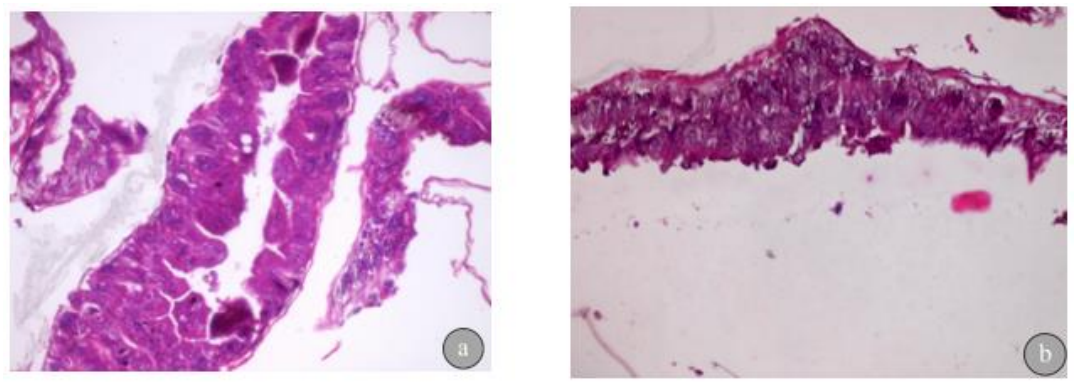

Fig. 3: Cross-sections of the midgut of Rhynchophorus ferrugineus larva in control treatment showed:

a: Normal structure of lining epithelial. b: Normal Columnar epithelial lining.

$(\mathrm{H} \& \mathrm{E} \times 400)$

(H \& E $\times 400$
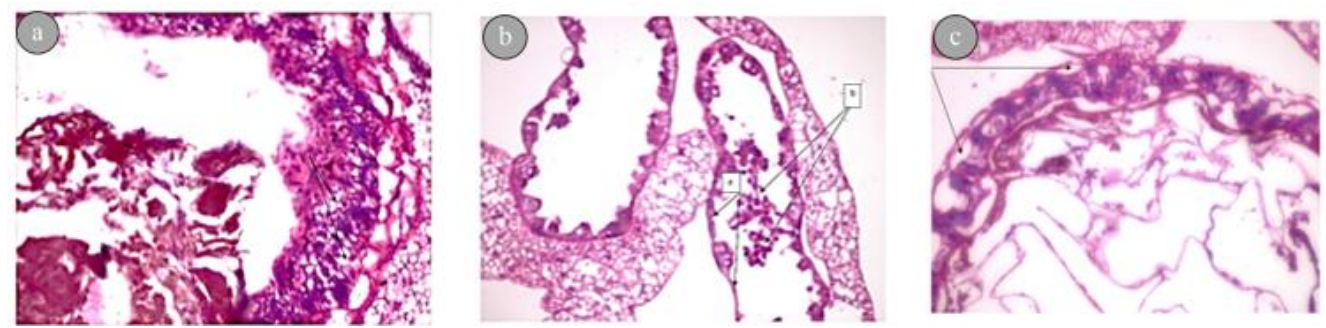

Fig. 4: Cross-section of the midgut of Rhynchophorus ferrugineus larva treated with chlorpyrifos showed:

a: Vacuolar degeneration of the epithelial lining.

$(\mathrm{H} \& \mathrm{E} \times 400)$

b: Thinning $(a)$ and desquamation $(b)$ of epithelial lining in the lumen. $\quad(\mathrm{H} \& \mathrm{E} \times 400)$

c: Necrosis of epithelial cells lining with separation of the basement membrane. $(\mathrm{H} \& \mathrm{E} \times 400)$
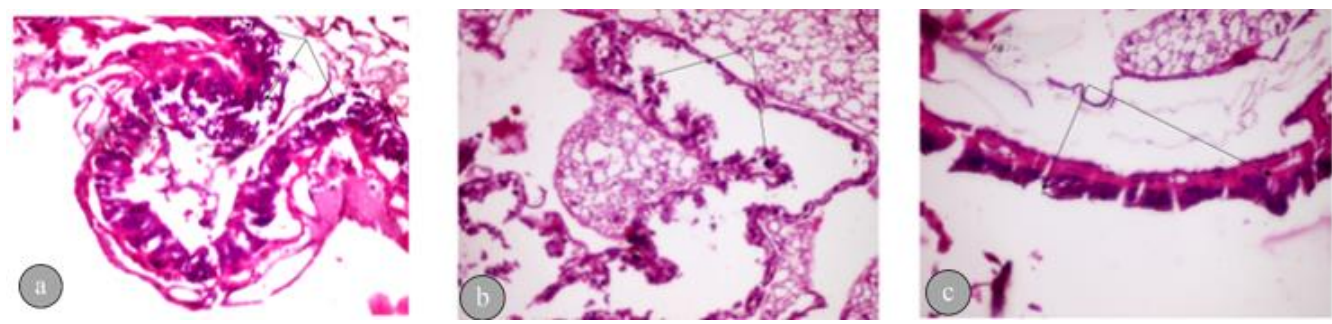

Fig. 5: Cross-section of the midgut of Rhynchophorus ferrugineus larva treated with methomyl showed:

a: Sever destruction and necrosis of epithelial lining with separation of the basement membrane. (H \& E $\times$ 400)

b: Sever degeneration and necrosis of epithelial lining with desquamation in its lumen.

$(\mathrm{H} \& \mathrm{E} \times 400)$

c: Thinning and necrosis of the epithelial lining.

$(\mathrm{H} \& \mathrm{E} \times 400)$
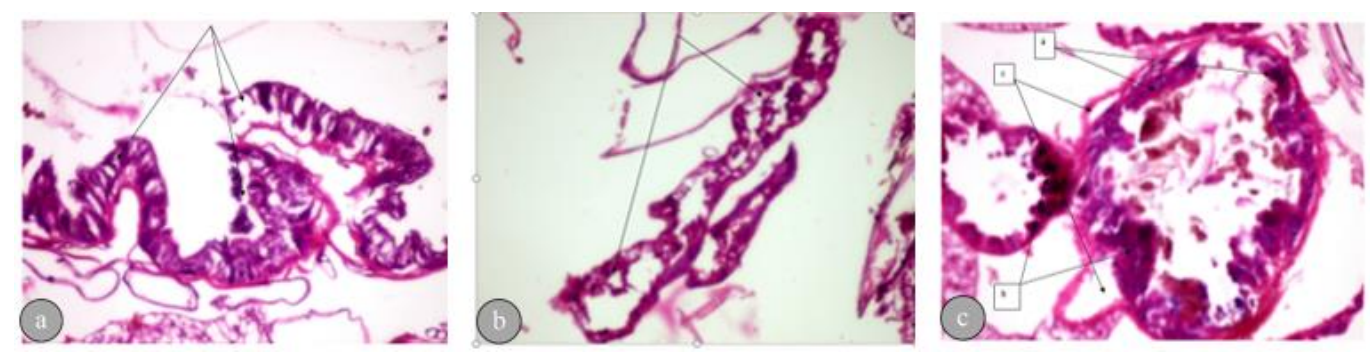

Fig. 6: Cross-section of the midgut of Rhynchophorus ferrugineus larva treated with spinosad showed:

a: Sever vacuolar degeneration and necrosis of epithelial lining with separation of the basement membrane. $(\mathrm{H} \& \mathrm{E} \times 400)$

b: Sever destruction and necrosis of epithelial lining. $\quad(\mathrm{H} \& \mathrm{E} \times 400)$

c: Sever necrosis $(a)$ and proliferation of epithelia lining $(b)$ with destruction and separation of basement membrane $(c) . \quad(\mathrm{H} \& \mathrm{E} \times 400)$ 


\section{CONCLUSION}

The biochemical and histopathological responses of $R$. ferrugineus to sub-lethal levels ( $\mathrm{LC}_{50}$ values) of the tested insecticides displays changes in the enzymatic activities but it's agreed in its effectiveness on AChE inhibition and increasing total protein content and transaminases activity however methomyl showed a constant trend in increasing ALT and AST activity in contrast to spinosad. Chlorpyrifos was only induced by increasing protein carbonyl (oxidative stress indicator) followed by increasing antioxidant enzymes (Catalase). Exposure RPW accompanied with lower GST and GPx activities especially in spinosad then chlorpyrifos treatments. Cross-section of the midgut of RPW larva treated with the tested insecticides show various histopathological responses was spinosad > methomyl > chlorpyrifos.

\section{REFERENCES}

Abbott, W.S., 1925. A method of computing the effectiveness of an insecticide. Journal of Economic Entomology, 18, 265-267. https://doi.org/10.1093/jee/18.2.265a

Abd El-Fattah, A.Y., Abd El-Wahab, A.S., Jamal, Z.A., El-Helaly, A.A., 2020. Histopathological studies of red palm weevil Rhynchophorus ferrugineus,(Olivier) larvae and adults to evaluate certain nano pesticides. Brazilian Journal of Biology, 81, 195-201.

Abd-El-Aziz, H., 2014. Effect of some insecticides on certain enzymes of Spodoptera littoralis (Bosid.). Egyptian Journal of Agricultural Research, 92, 501-512.

Abdel-Ghaffar, A.A., 2004. Phagodetervency induced by Margosan-0 as compined with sesam oil against the berseem hopper Euprepocnemis plorans (Charp) (Orthoptera: Acididae). Journal of Egyptian-German Society of Zoology, 43 E, 69-86.

Abdel-Razik, M.A., Mahmoud, S.A., 2017. Toxicological and biochemical effects of jojoba, Simmondsia chinensis extract on cotton leafworm, Spodoptera littoralis (Boisd.). Journal of Plant Protection and Pathology, 8, 233-239.

Abdel-Salam, A.H., EL-Bana, A., El-Rehewy, E., 2014. Evaluation of some insecticides on infestation of red palm weevil Rhynchophorus ferrugineus (Olivier)(Coleoptera: Curculionidae). Journal of Plant Protection and Pathology, 5, 567-571.

Abdelsalam, S., Alzahrani, A.M., Elmenshawy, O.M., Abdel-Moneim, A.M., 2020. Antioxidant status and ultrastructural defects in the ovaries of red palm weevils (Rhynchophorus ferrugineus) intoxicated with spinosad. Entomological Research, 50, 309-316.

Abdelsalam, S.A., Alzahrani, A.M., Elmenshawy, O.M., Abdel-Moneim, A.M., 2016. Spinosad induces antioxidative response and ultrastructure changes in males of red palm weevil Rhynchophorus ferrugineus (Coleoptera: Dryophthoridae). Journal Insect Science, 16, 1-10.

Aebi, H., 1984. Catalase in vitro, in: Methods in Enzymology. Academic press New York, pp. 121-126.

Ahmed, F.A., 1995. Safety and efficiency of natural and synthetic insecticides used in the control of culicine mosquitoes in Egypt (PhD Thesis). Faculty of Science, Zagazig University, Egypt.

Al-Dosary, N.M., Al-Dobai, S., Faleiro, J.R., 2016. Review on the management of red palm weevil Rhynchophorus ferrugineus Olivier in date palm Phoenix dactylifera L. Emirates Journal of Food and Agriculture, 34-44.

Ali, S., Zhang, C., Wang, Z., Wang, X.-M., Wu, J.-H., Cuthbertson, A.G., Shao, Z., Qiu, B.L., 2017. Toxicological and biochemical basis of synergism between the 
entomopathogenic fungus Lecanicillium muscarium and the insecticide matrine against Bemisia tabaci (Gennadius). Scientific Reports, 7, 1-14.

Amin, T.R., Fahmy, N.M., 2011. Impact of spinetoram on some nitrogenous components related to protein metabolites in the cotton leaf worm, Spodoptera littoralis (Biosd.). Egyptian Academic Journal of Biological Sciences. C, Physiology and Molecular Biology, 3, 51-64.

Arafa, O.E., 2020. Field evaluation of synthetic pheromone, allomone, palm kairmone and ester in capturing adult red palm weevils, Rhynchophorus ferrugineus (olivier) by aggregation pheromone traps in date palm plantations. Plant Archives, 20, 18571862.

Araujo, R. dos S., Lopes, M.P., Barbosa, W.F., Gonçalves, W.G., Fernandes, K.M., Martins, G.F., Tavares, M.G., 2019. Spinosad-mediated effects on survival, overall group activity and the midgut of workers of Partamona helleri (Hymenoptera: Apidae). Ecotoxicology and Environmental Safety, 175, 148-154. https://doi.org/10.1016/ j. ecoenv.2019.03.050

Assar, A.A., Abo El-Mahasen, M.M., Dahi, H.F., Amin, H.S., 2016. Biochemical effects of some insect growth regulators and bioinsecticides against cotton leafworm, Spodoptera littoralis (Boisd.)(Lepidoptera Noctuidae). Journal of Bioscience and Applied Research, 2, 587-594.

Azmi, M.A., Naqvi, S.N.H., Khan, M.F., Akhtar, K., Khan, F.Y., 1998. Comparative toxicological studies of RB-a (Neem Extract) and Coopex (Permethrin+ Bioallethrin) against Sitophilus oryzae with reference to their effects on oxygen consumption and GOT, GPT activity. Turkish Journal of Zoology, 22, 307-310.

Beutler, E., Duron, O., Kelly, B.M., 1963. Improved method for the determination of blood glutathione. The Journal of Laboratory and Clinical Medicine, 61, 882-888.

Bourne, Y., Sharpless, K.B., Taylor, P., Marchot, P., 2016. Steric and dynamic parameters influencing in situ cycloadditions to form triazole inhibitors with crystalline acetylcholinesterase. Journal of the American Chemical Society, 138, 1611-1621.

Bradford, M.M., 1976. A rapid and sensitive method for the quantitation of microgram quantities of protein utilizing the principle of protein-dye binding. Analytical Biochemistry, 72, 248-254. https://doi.org/10.1016/0003-2697(76)90527-3

Bucur, M.P., Bucur, B., Marty, J.-L., Radu, G.-L., 2014. In vitro investigation of anticholinesterase activity of four biochemical pesticides: spinosad, pyrethrum, neem bark extract and veratrine. Journal of Pesticide Science, 39, 48-52. https://doi.org/10.1584/jpestics.D13-062

Che-Mendoza, A., Penilla, R.P., Rodríguez, D.A., 2009. Insecticide resistance and glutathione S-transferases in mosquitoes: a review. African Journal of Biotechnology, 8.

Claudianos, C., Ranson, H., Johnson, R.M., Biswas, S., Schuler, M.A., Berenbaum, M.R., Feyereisen, R., Oakeshott, J.G., 2006. A deficit of detoxification enzymes: pesticide sensitivity and environmental response in the honeybee. Insect Molecular Biology, $15,615-636$.

Dalle-Donne, I., Rossi, R., Giustarini, D., Milzani, A., Colombo, R., 2003. Protein carbonyl groups as biomarkers of oxidative stress. Clinica Chimica Acta, 329, 23-38. https://doi.org/10.1016/S0009-8981(03)00003-2

Dembilio, Ó., Jaques, J.A., 2012. Bio-ecology and integrated management of the red palm weevil, Rhynchophorus ferrugineus (Coleoptera: Curculionidae), in the region of Valencia (Spain). Hellenic Plant Protection Journal, J. 5, 1-12.

Durlin, P., Gauvrit, C., Aranda, G., 1987. Methomyl analogues with increased biological activity towards F7T maize mitochondria. Phytochemistry, 26, 1909-1913. 
El, S.T.S., Sayed, R.M., Rizk, S.A., Abdalla, R.S., 2020. Toxicological and histological studies on the effect of spinosad or vinegar on Culex pipiens larvae (Diptera: Culicidae). African Entomology, 28, 175-181. https://doi.org/10.4001/003. 028.0175

Elgohary, L.R.A., Abd-El-Hady, A.A., Abd-El-Hady, F.M., 2015. Efficacy of certain insecticides against red palm weevil, Rhynchophorus ferrugineus (Olivier) under laboratory and field conditions. Journal of Plant Protection and Pathology, 6, 5564. https://doi.org/10.21608/jppp.2015.53064

Ellman, G.L., Courtney, K.D., Andres Jr, V., Featherstone, R.M., 1961. A new and rapid colorimetric determination of acetylcholinesterase activity. Biochemical Pharmacology, 7, 88-95.

Etebari, K., Mirhoseini, S.Z., Matindoost, L., 2005. A study on interaspecific biodiversity of eight groups of silkworm (Bombyx mori) by biochemical markers. Insect Science, $12,87-94$.

Faleiro, J.R., 2006. A review of the issues and management of the red palm weevil Rhynchophorus ferrugineus (Coleoptera: Rhynchophoridae) in coconut and date palm during the last one hundred years. International Journal of Tropical Insect Science, 26, 135-154.

Faleiro, J.R., Abdallah, A.B., Kumar, J.A., Shagagh, A., Al Abdan, S., 2010. Sequential sampling plan for area-wide management of Rhynchophorus ferrugineus (Olivier) in date palm plantations of Saudi Arabia. International Journal of Tropical Insect Science, 30, 145-153.

Fanucchi, M.V., 2004. Development of antioxidant and xenobiotic metabolizing enzyme systems, in: The Lung. Elsevier, pp. 177-185.

Felton, G., 1995. Antioxidant defenses of invertebrates and vertebrates in Oxidative Stress and Antioxidant Defenses in Biology (ed. Ahmad, S.) 356-434.

Finney, D.J., 1971. Probit analysis, 3rd ed. Cambridge University Press. Cambridge, UK.

Gaaboub, I.A., El-Kady, H.A., El-Khayat, E.F., El-Shewy, A.M., 2012. Biochemical and histological effect of some plant extracts, insecticide (methomyl) and bio insecticide (protecto) against cotton leafworm, Spodoptera littoralis (Boisd.), in: $1^{\text {st }}$ International Conf. of Biotchnology Applicotions in Agriculture. Benha Univ., Proce. pp. 21-32.

Giblin-Davis, R.M., Faleiro, J.R., Jacas, J.A., Peña, J.E., Vidyasagar, P., 2013. Biology and management of the red palm weevil, Rhynchophorus ferrugineus. Potential Invasive Pests Agric. Crops Eds Peña JE 1-34.

Gupta, R.C., 2011. Toxicology of organophosphate and carbamate compounds. Academic Press.

Habig, W.H., Pabst, M.J., Jakoby, W.B., 1974. Glutathione S-transferases the first enzymatic step in mercapturic acid formation. Journal of Biological Chemistry, 249, 71307139.

Hamadah, K.S., 2019. Disturbance of phosphatase and transaminase activities in grubs of the red palm weevil Rhynchophorus ferrugineus (Coleoptera: Curculionidae) by certain insecticidal compounds. The Journal of Basic and Applied Zoology, 80, 18.

Haynes, K.F., 1988. Sublethal effects of neurotoxic insecticides on insect behavior. Annual Review of Entomology, 33, 149-168.

Hussein, M.A., Hafez, S.E., El-Sherif, L.S., Hewady, M.A., 1994. Histopathological effects of chamomile against larvae of spiny bollworm, Earias insulana (F. Noctuidae: Lepidoptera). Journal of Faculty Education, 19, 178-200. 
Jia, M., Cao, G., Li, Y., Tu, X., Wang, G., Nong, X., Whitman, D.W., Zhang, Z., 2016. Biochemical basis of synergism between pathogenic fungus Metarhizium anisopliae and insecticide chlorantraniliprole in Locusta migratoria (Meyen). Scientific Reports, 6, 1-15.

Kaakeh, W., Abou-Nour, M.M., Khamis, A.A., 2001. Mass rearing of the red palm weevil, Rhynchophorus ferrugineus Oliv., on sugarcane and artificial diets for laboratory studies: illustration of methodology, in: Proceedings of the Second International Conference on Date Palm, Al-Ain, UAE. pp. 344-357.

Lopes, M.P., Fernandes, K.M., Tomé, H.V.V., Gonçalves, W.G., Miranda, F.R., Serrão, J.E., Martins, G.F., 2018. Spinosad-mediated effects on the walking ability, midgut, and Malpighian tubules of Africanized honey bee workers. Pest Management Science, 74, 1311-1318. https://doi.org/10.1002/ps.4815

Magdy, M., Moawad, F.G., Elsayed, N.E., Nasr Sherif, S.A., 2019. Biochemical and Toxicological Studies of Some Pesticides on Cotton leafworm (Spodoptera littoralis). Arab Universities Journal of Agricultural Sciences, 27, 2489-2499.

Mampallil, L.J., Faizal, M.H., Anith, K.N., 2017. Bacterial bioagents for insect pest management. Journal of Entomology and Zoology Studies, 5, 2237-2244.

Marklund, S., Marklund, G., 1974. Involvement of the superoxide anion radical in the autoxidation of pyrogallol and a convenient assay for superoxide dismutase. European Journal of Biochemistry, 47, 469-474.

Mashal, M.M., Obeidat, B.F., 2019. The efficacy assessment of emamectin benzoate using micro injection system to control red palm weevil. Heliyon 5, e01833.

Megahed, M.M.M., El-Tawil, M.F., El-Bamby, M.M.M., Abouamer, W.L., 2013. Biochemical effects of certain bioinsecticides on cotton leaf worm, Spodoptera littoralis (Boisd.)(Lepidoptera: Noctuidae). Research Journal of Agriculture and Biological Sciences, 9, 308-317.

Mertz, F.P., Yao, R.C., 1990. Saccharopolyspora spinosa sp. nov. isolated from soil collected in a sugar mill rum still. International Journal of Systematic and Evolutionary Microbiology, 40, 34-39.

Milosavljević, I., El-Shafie, H.A., Faleiro, J.R., Hoddle, C.D., Lewis, M., Hoddle, M.S., 2019. Palmageddon: the wasting of ornamental palms by invasive palm weevils, Rhynchophorus spp. Journal of Pest Science, 92, 143-156.

Müller, C., 2018. Impacts of sublethal insecticide exposure on insects-Facts and knowledge gaps. Basic and Applied Ecology, 30, 1-10.

Murphy, S.T., Briscoe, B.R., 1999. The red palm weevil as an alien invasive: biology and the prospects for biological control as a component of IPM. Biocontrol News and Information, 20, 35N-46N.

Naqvi, S., Tabassum, R., Azmi, M., Hafez, A., Tariq, R., Rashid, N., 1994. Histopathological effects of danitol (Fenpropathrin) and neem fraction on grasshopper, Heteracris annulosa (Wak) gut and changes in enzyme pattern, in: Proceedings of Pakistan Congress of Zoology. p. 2532.

Nathan, S.S., Choi, M.Y., Seo, H.Y., Paik, C.H., Kalaivani, K., Kim, J.D., 2008. Effect of azadirachtin on acetylcholinesterase (AChE) activity and histology of the brown planthopper Nilaparvata lugens (Stål). Ecotoxicology and Environmental Safety, 70, 244-250.

Rabea, E.I., Nasr, H.M., Badawy, M.E.I., 2010. Toxic Effect and Biochemical Study of Chlorfluazuron, Oxymatrine, and Spinosad on Honey Bees (Apis mellifera). Archives of Environmental Contamination and Toxicology, 58, 722-732. https://doi.org/10.1007/s00244-009-9403-y 
Reitman, S., Frankel, S., 1957. A colorimetric method for the determination of serum glutamic oxalacetic and glutamic pyruvic transaminases. American Journal of Clinical Pathology, 28, 56-63.

Sabri, M.A., Islam, M.S., Hussain, D., Saleem, M., 2017. Evaluation of lethal response of biorational insecticides against Spodoptera litura (Lepidoptera: Noctuidae). Journal Entomology and Zoology Studies, 4, 270-274.

Salama, H.S., Abdel-Razek, A.S., 2002. Development of the red palm weevil, Rhynchophorus ferrugineus (Olivier),(Coleoptera, Curculionidae) on natural and synthetic diets. Anzeiger Für Schädlingskunde= Journal of Pest Science, 75, 137139.

Saleh, M.R.A., 1992. Red palm weevil, Rhynchophorus ferrugineus (Olivier).The first record for Egypt and indeed the African Continent, List No. 10634 Africa, Collection No. 22563. British Museum, Report of International Institute of Entomology, 56 Queen's Gate, London, SW 75 JR UK.

Salem, S.A., El-Salam, A.A., El-Kholy, M.Y., 2018. The optimal use of some types of natural food attractive as a tool to reduce the prediction and limit the spread of red palm weevil Rhynchophorus ferrugineus Olivier. Bioscience Research, 15, 29112918.

Salgado, V.L., 1998. Studies on the Mode of Action of Spinosad: Insect Symptoms and Physiological Correlates. Pesticide Biochemistry and Physiology, 60, 91-102. https://doi.org/10.1006/pest.1998.2332

Sallam, A.A., El-Shafie, H.A.F., Al-Abdan, S., 2012. Influence of farming practices on infestation by red palm weevil Rhynchophorus ferrugineus (Olivier) in date palm: a case study. Journal of Agricultural Science and Soil Science, 2, 370-376.

Salman, T.A.A., Abbas, M.K., Mandour, N.S.A., Osman, M.A.M., El-Kady, G.A., 2020. Efficacy of chemical, biological insecticides and plant extracts against red palm weevil Rhynchophorus ferrugineus (Curculionidae: Coleoptera) under laboratory and field conditions. Egyptian Journal of Plant Protection Research Institute, 3, 964-972.

Samarghandian, S., Afshari, R., Farkhondeh, T., 2014. Effect of long-term treatment of morphine on enzymes, oxidative stress indices and antioxidant status in male rat liver. International Journal of Clinical and Experimental Medicine, 7, 1449-1453.

Shawir, M., Abbassy, A., Mohamed Salem, Y., 2014. Laboratory evaluation of some insecticides against larval and adult stages of red palm weevil's Rhynchophorus ferrugineus (Olivier). Alexandria Science Exchange Journal, 35, 75-79.

Shuang-yang, D., Huai-ye, L., Xue-feng, L., Zhi-yi, Z., 2001. Effects of two kinds of transgenic poplar on protective enzymes system in the midgut of larvae of American white moth. Journal of Forestry Research, 12, 119-122.

Simon, J.Y., 1996. Insect glutathione S-transferases. Zoological Studies, 35, 9-19.

Söğüt, İ., Şenat, A., İlhan, A.O., Sezen, A., Erel, Ö., 2021. Evaluation of Thiol/Disulfide Homeostasis and Other Oxidative Stress Markers in Patients Undergoing Hemodialysis. Turkish Journal of Nephrology, 30, 17-24.

Sun, Y.-P., 1950. Toxicity Index-an improved Method of comparing the relative 378 Toxicity of Insecticides. Journal of Economic Entomology, 43, 45-53.

Suvarna, K.S., Layton, C., Bancroft, J.D., 2018. Bancroft's theory and practice of histological techniques, $8^{\text {th }}$ ed. Elsevier Health Sciences.

Tomlin, C.D., 2009. The pesticide manual: a world compendium. British Crop Production Council. 
Vacas, S., Primo, J., Navarro-Llopis, V., 2013. Advances in the use of trapping systems for Rhynchophorus ferrugineus (Coleoptera: Curculionidae): traps and attractants. Journal of Economic Entomology, 106, 1739-1746.

Vale, A., Lotti, M., 2015. Organophosphorus and carbamate insecticide poisoning. Handbook of Clinical Neurology, 131, 149-168.

Vontas, J.G., Small, G.J., Hemingway, J., 2001. Glutathione S-transferases as antioxidant defence agents confer pyrethroid resistance in Nilaparvata lugens. Biochemical Journal, 357, 65-72.

Wakil, W., Yasin, M., Qayyum, M.A., Ghazanfar, M.U., Al-Sadi, A.M., Bedford, G.O., Kwon, Y.J., 2018. Resistance to commonly used insecticides and phosphine fumigant in red palm weevil, Rhynchophorus ferrugineus (Olivier) in Pakistan. Plos One, 13, e0192628.

Yan, L.-J., Traber, M.G., Packer, L., 1995. Spectrophotometric method for determination of carbonyls in oxidatively modified apolipoprotein B of human low-density lipoproteins. Analytical Biochemistry, 228, 349-351.

Yin, X.H., Wu, Q.J., Li, X.F., Zhang, Y.J., Xu, B.Y., 2008. Effect of sublethal concentrations of spinosad on the activities of detoxifying enzymes in the larvae of diamondback moth Plutella xylostella. Chinese Journal of Pesticide Science, 10, 28-34.

\footnotetext{
ARABIC SUMMARY

الاستجابات الكيموحيوية والنسيجية لسوسة النخيل الحمراء Rhynchophorus ferrugineus المعرضة

لمستويات شبه المميتة من مبيدات حشرية تابعة لمجموعات مختلفة

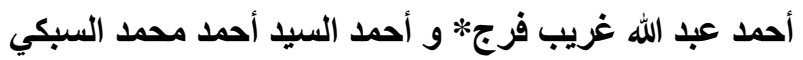

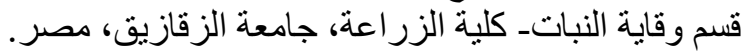

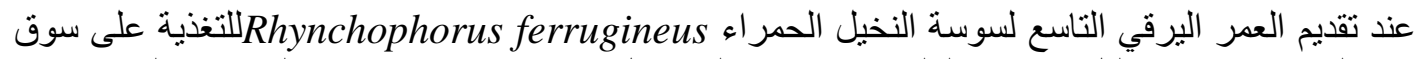

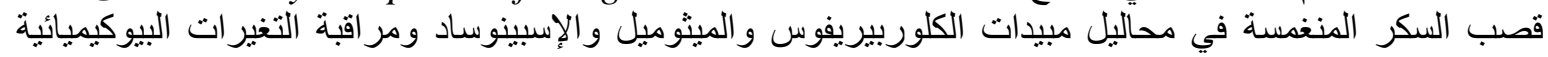

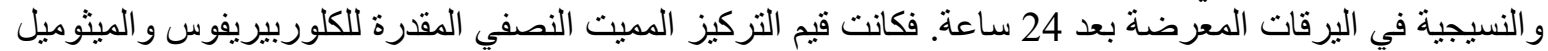

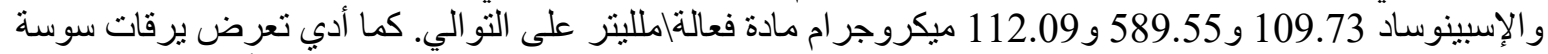

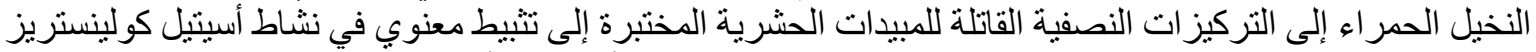

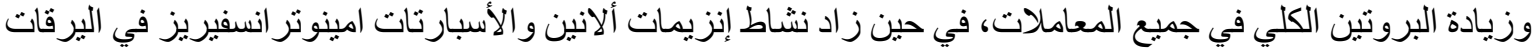

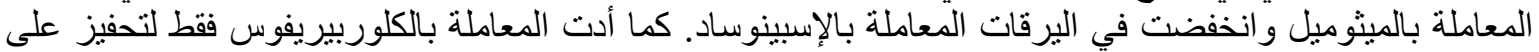

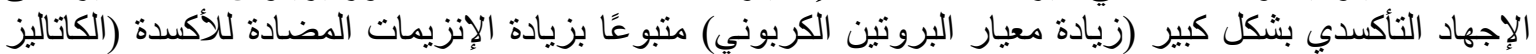

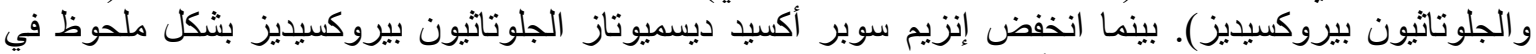

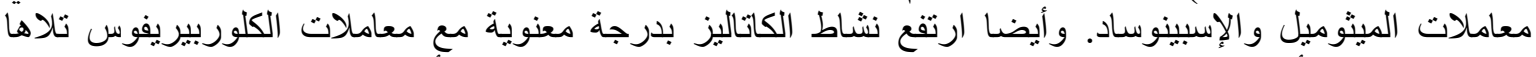

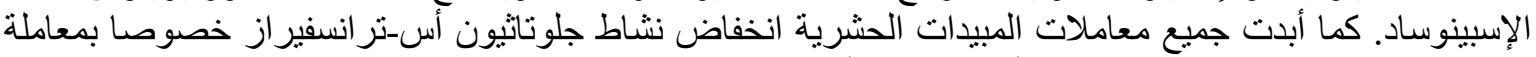

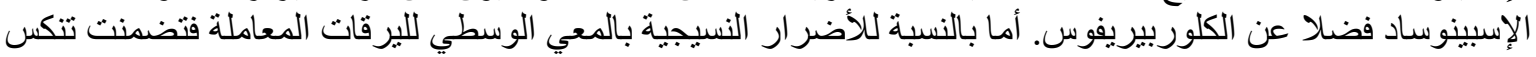

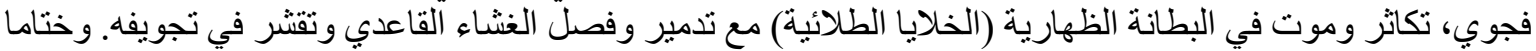

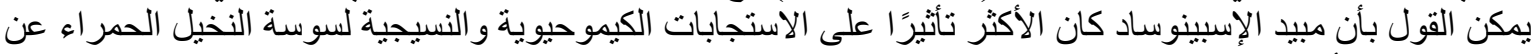

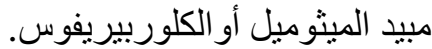

